\title{
PENGARUH PEMBERIAN UMPAN BALIK DAN KEMAMPUAN MOTORIK TERHADAP HASIL BELAJAR SHOOTING SISWA SMP NEGERI DIKECAMATAN LANGSA KOTA
}

\author{
Cut Cinta Dewi ${ }^{1}$ dan Harun Sitompul ${ }^{2}$ \\ Guru SMP Negeri 7 Langsal, Pascasarjana Universitas Negeri Medan ${ }^{2}$ \\ cutcintadewi@yahoo.co.id ${ }^{l}$,prof_runsit@yahoo.com ${ }^{2}$
}

\begin{abstract}
Abstrak : Penelitian ini bertujuan : (1) menguji pengaruh pemberian umpan balik dan kemampuan motorik terhadap hasil belajar Shooting. (2). Meningkatkan kemampuan motorik siswa (3). Meningkatkan hasil belajar siswa di kota langsa, penelitian ini menggunakan metode quasi eksperimen dengan disain faktorial $2 \times 2$. Populasi penelitian ini adalah siswa SMP Negeri 1 Langsa kelas VII yang berjumlah 77 orang, dan siwa SMP Negeri 7 sampel berjumlah 76 orang yang diperoleh melalui cluster random sampling. Instrumen penelitian ini menggunakan tes kemampuan motorik dan tes hasil belajar shooting sepakbola. Untuk tes kemampuan motorik digunakan tes motor ability yaitu tes kemampuam motorik terdiri dari ; standing broad jump, Soccer drible, zig-zag run,shutle run dan lari cepat 50 meter Tes hasil belajar shooting sepakbola dikonstruksikan berdasarkan instrumen tes hasil belajar shooting sepakbola yang disesuaikan dengan kurikulum 2013 kelas VII semester I, yang memiliki realibilitas 0.71
\end{abstract}

Kata Kunci : Pemberian Umpan Balik, dan Kemampuan Motorik, Hasil Belajar Shooting.

Abstract : This aimed of the research deal the effects of presenting the feedback and motoric ability toward the football shooting learning outcome for student on Junior High School 1, amounting to $=77$ people and student Junior High school 7, amounting to 76 people. Which obtained through random cluster sampling. The research instrument used motor ability test and test result to learn shooting football to test the ability of the motor used test of motor abilities, namely learning motor skills consist of : Standing broad jump, Football drible, zig-zag run, shuttle run, and sprint 50 yards. Achievement test shooting football curriculum tailored to the first semester of 2013 class VII has a reabilities of $=0.71$

Keyword: Presenting the feedback and motoric ability, shooting learning out come.

\section{PENDAHULUAN}

Olahraga merupakan kegiatan yang dilakukan manusia untuk mencapai kesehatan dan kebugaran (Schmid, 2005 : 32). Seorang filosof dari Catholic of Amerika mengemukakan bahwa olahraga adalah suatu perluasan atau perkembangan lebih lanjut dari bermain dan nilai-nilai intinya diambil dari kegiatan bermain tersebut. Pendapat lainnya Matveyev (2008 : 68) mengemukakan olahraga adalah suatu kegiatan otot-otot yang energik dimana seorang atlet memperagakan kemampuan geraknya atau kemampuan motoriknya dan kemaunnya semaksimal mungkin. Pada saat sekarang ini yang paling menarik perhatian adalah, bahwa olahraga di Indonesia meskipun belum merata secara menyeluruh, tetapi telah diterima oleh masyarakat. Olahraga tumbuh dan berkembang dalam berbagai bentuk dengan cara pelaksanaan, pengorganisasian dan tujuan yang berbeda-beda sesuai dengan penekanannya masing-masing.

Pendidikan jasmani merupakan bagian integral dari pendidikan secara keseluruhan, yang bertujuan mengembangkan aspek kesehatan, kesegaran jasmani, keterampilan berfikir secara kritis, penalaran dan keterampilan sosial melalui aktivitas jasmani olahraga. Hal ini sesuai dengan pernyataan (Kemendikbud, 2007 : 13) pendidikan akan kurang lengkap tanpa pendidikan jasmani karena pendidikan jasmani merupakan bagian pendidikan secara keseluruhan" Pendidikan Jasmani mengutamakan aktivitas jasmani, mental sosial serta emosional serasi, selaras dan seimbang, sehingga dalam penyelenggaraan pendidikan jasmani memberikan kesempatan kepada siswa untuk terlibat langsung dalam aneka pengalaman belajar melalui aktivitas 
jasmani dan olahraga yang dilakukan secara sistematis.

Salah satu cabang olahraga yang ada di dalam kurikulum pendidikan jasmani adalah Sepakbola. Sepakbola adalah salah satu cabang olahraga yang paling digemari oleh masyarakat, yang telah dilakukan oleh manusia sejak 3000 tahun yang lalu sampai saat ini.

Permainan sepak bola sekarang ini mengalami beberapa perubahan besar, baik dilihat dari teknik permainan, peraturanperaturan, pengorganisasian atau dipandang dari sudut publikasi sepakbola berkembang sangat cepat, dan hampir diseluruh belahan dunia menyukai sepakbola. Di kancah Internasional sepakbola mempunyai wadah organisasi tertinggi yaitu FIFA (Federation International Foodball Assosiation). Dalam permainan sepakbola juga diharuskan untuk bekerja sama dalam satu Tim.

Sepakbola merupakan permainan beregu, masing-masing regu terdiri dari sebelas pemain, dan salah satunya penjaga gawang. Permainan ini hampir seluruhnya dimainkan dengan menggunakan seluruh bagian kaki, kepala dan dada. Untuk penjaga gawang diperbolehkan menggunakan tangan dan lengannya di daerah tendangan hukumannya. Tujuan permainan sepakbola adalah pemain berusaha memasukkan bola sebanyakbanyaknya ke gawang lawan dan berusaha menjaga gawangnya sendiri agar tidak kemasukan bola dan dengan menggunakan teknik yang benar dalam bermain sepakbola. Menurut Muchtar (1989 : 14) teknik dasar bermain sepakbola terdiri dari : menendang bola, menyundul bola (heading), menggiring bola (dribling), merebut bola (tacking), bola lemparan ke dalam (throwing-in), teknik penjaga gawang (goal keeping). Teknik dasar akan berkembang dari gerakan dasar menuju gerakan lanjut yang lebih komplet. Dengan menguasai teknik dasar dan kemampuan motorik yang tinggi pemain tersebut maka seorang dapat bermain sepakbola dengan benar - Shooting merupakan salah satu teknik dasar yang harus mendapatkan perhatian yang ekstra dari guru /pelatih yang mengajarkan sepakbola karena penentuan kemenangan adalah dari tendangan langsung ke gawang lawan, dan untuk mendapatkan hasil yang maksimal pemain harus memiliki kemampuan motorik yang tinggi sehingga memiliki power yang tinggi untuk dapat menghasilkan tendangan tepat ke gawang lawan. Dan perhatian pelatih untuk dapat memberikan sugesti melalui umpan balik juga sangat diperlukan agar pemain mengetahui tingkat kebenaran dan kesalahan dalam melakukan suatu gerakan pada saat permainan sepak bola.

Dari kenyataan yang ada, hasil prestasi hasil shooting pemain sepak bola banyak yang harus diperbaiki, baik dari segi kecepatan waktu pada saat menendang dan hasil dari tendangan langsung ke kegawang (shooting) pada saat event nasional maupun tingkat internasional, maka hal ini perlu dijadikan bahan pemikiran. Bila kita ingin mencapai prestasi maksimal dalam permainan sepak bola tentu banyak aspek yang perlu diperhatikan, karena pada saat melakukan shooting diperlukan kemampuan fisik yang cukup tinggi, kemampuan motorik yang baik teknik yang benar serta kekuatan untuk dapat menendang bola kegawang. Untuk mengetahui hasil shooting yang dilakukan oleh siswa peneliti melakukan observasi (pengamatan) yang selama beberapa tahun belakangan ini di dan memperoleh informasi dari guru Penjas Lainnya di SMP Negeri 3 dan SMP Negeri 1 kota langsa

Hasil pengamatan peneliti selama ini di sekolah-sekolah khususnya di Sekolah Menengah Pertama Negeri (SMPN) ternyata banyak siswa yang tidak dapat mencapai target kelulusan pada materi pembelajaran shooting yang telah ditetapkan. Standar untuk kelulusan materi pembelajaran shooting adalah > 74 . (Nurhasan 1990 : 47) tetapi standar ini masih belum tercapai

Menurut pandangan kognitifisme, belajar bukan hanya pembentukan tingkah laku yang diperoleh karena pengulangan hubungan Stimulus-Respon (S-R) dan adanya reward serta reinforcement, tetapi merupakan fungsi pengalaman perseptual dan proses kognitif yang mencakup ingatan, retensi, lupa, pengolahan informasi. Proses belajar adalah mengatur stimulus yang diterima dan menyesuaiakan dengan struktur kognitif yang sudah ada atau diperoleh berdasarkan pengalaman sebelumnya sehingga terjadi perubahan dalam tingkah laku.

Gagne (1977 : 58) berpendapat bahwa di dalam proses belajar terdapat dua fenomena, yaitu (1) ketrampilan intelektual yang meningkat sejalan dengan meningkatnya umur serta latihan yang diperoleh individu, dan (2) belajar akan lebih cepat apabila strategi kognitif dapat dipakai dalam memecahkan masalah secara lebih efisien. Selanjutnya Gagne (1977 : 58) menyatakan bahwa dalam pembelajaran 
terjadi proses penerimaan informasi untuk kemudian diolah sehingga menghasilkan keluaran dalam bentuk hasil belajar.

Menurut gambaran Oxendine (1968: 67) belajar adalah (1) akumulasi pengetahuan, (2) penyempurnaan suatu kegiatan, (3) pemecahan masalah, dan (4) penyesuaian situasi yang berubah-ubah. Makna belajar dapat juga diartikan sebagai kemampuan untuk menghasilkan keterampilan berbuat, karena itu belajar dapat diartikan sebagai peristiwa, kejadian, atau perubahan yang terjadi apabila seseorang berlatih memungkinkan mereka terampil dalam melaksanakan suatu kegiatan. Belajar adalah hasil langsung, karena proses yang mengantarkan perubahan berlangsung secara internal, kecuali diartikan berdasarkan perubahan prilaku itu sendiri Skinner dalam Olson (2008 : 35) juga sangat tertarik untuk membahas teori belajarnya ke proses pendidikan. Skinner menyatakan belajar akan berlangsung sangat efektif apabila (1) informasi yang akan dipelajari dipelajari dan disajikan secara bertahap, (2) pembelajar segera diberi umpan balik (feedback) mengenai akurasi pembelajaran mereka, (3) pembelajar mampu belajar dengan caranya sendiri. Selanjutnya Campbell (1996 : 70) mengartikan kecepatan belajar tergantung kepada : (1) kemampuan dari individu, (2) tingkatan motivasi, (3) tugas-tugas yang diberikan, peserta didik yang memiliki kemampuan motorik tinggi akan lebih cepat mengembangkan kemampuan-kemampuan fisiknya dari peserta didik yang memiliki kemampuan motorik rendah.

Setelah seseorang mengikuti proses belajar dalam waktu tertentu barulah ia akan memperoleh hasil belajar. Gagne (1977:65) menyatakan bahwa belajar yang terjadi pada manusia dapat memperoleh perubahan prilaku sebagai hasil belajar disebut juga dengan kemampuan yang meliputi : (1) informasi verbal, yaitu kemampuan untuk mengungkapkan pengetahuan dalam bentuk bahasa lisan maupun tertulis, penguasaan informasi verbal yang baik memungkinkan individu berperan dalam kehidupan, (2) keterampilan intelektual, yaitu kemampuan yang berfungsi untuk berhubungan dengan lingkungan serta mempresentasikan konsep serta lambang, yang terdiri dari diskriminasi jamak, konsep konkrit, serta prinsip, (3) keterampilan motorik, yakni kemampuan melakukan serangkaian gerak jasmani dalam melakukan sesuatu hal secara terkoordinasi, (4) sikap, yaitu kemampuan menerima atau menolak objek berdasarkan penilaian terhadap objek tersebut, dan (5) strategi kognitif, yakni kemampuan mengarahkan aktifitas berfikir untuk memecahkan masalah. Keseluruhan kemampuan ini merupakan hasil interaksi kondisi internal peserta didik berupa potensi belajar dengan kondisi eksternal berupa rangsangan dari lingkungan melalui proses kognitif peserta didik. Hasil belajar seseorang adalah kemampuan internal yang telah menjadi milik pribadinya dan memungkinkan individu melakukan sesuatu atau memberikan dan memperlihatkan hasil tertentu.

Menurut Mielke (2007 : 70) shooting dapat dilakukan dengan berbagai cara di antaranya (1) Melakukan shooting secara langsung dari dribbling yang dilakukan. (2) Melakukan shooting dengan operan.

Menurut Merill (1978 : 56) belajar dapat digambarkan sebagai proses masukan (input) dan hasil (out put), yang secara bertahap dinilai sebagai informasi salah atau benar yang disebut juga dengan istilah umpan balik. Berdasarkan penjelasan dari teori hasil belajar, shooting merupakan gambaran dan tingkat kemampuann reacting yang diperoleh dalam bentuk pengetahuan dan keterampilan menurut Romizowski (1981 : 27) yang dituangkan ke dalam bentuk fakta, konsep, prinsip dan prosedur. Bentuk kemampuan yang menggambarkan tingkat kesanggupan reacting yaitu kemampuan yang berkaitan dengan keterampilan fisik diantaranya adalah Olahraga.

Menurut Schmid (1988 : 140) umpan balik adalah semua informasi hasil yang merupakan respon yang diterima selama atau setelah melakukan gerakan. Amezdros (2004 : 58) menyatakan umpan balik adalah semua informasi yang diterima atlet tentang penampilan dari skill, baik selama penampilan atau setelahnya.

Menurut Karwono (2008 : 45) umpan balik dapat dilakukan secara langsung maupun tidak langsung terhadap kemampuan peserta didik dalam mengelola pembelajaran. Dalam proses pembelajaran, umpan balik didasarkan atas pengamatan mengenai penampilan peserta didik, yaitu mengenai apakah proses belajarnya sudah mencapai tujuan atau belum. Umpan balik diartikan dengan memberitahukan kembali kepada peserta didik hasil pemahamannya yang salah atau kurang tepat serta memberitahukan konsep sebenarnya dan seharusnya dikuasai oleh peserta didik (Gultom. 
1994 : 67). Menurut Budiman (2007 : 15) umpan balik yaitu guru mengobservasi siswa secara individu dan menilai bagaimana siswa melakukan aktivitas serta apa yang harus dilakukan guru untuk meningkatkan kemampuan siswa itu. Pemikiran tersebut juga dituliskan oleh Slavin (2009 : 45) yang menyatakan bahwa umpan balik memiliki arti informasi tentang upaya seseorang, dalam hal ini mencakup kekurangan maupun kelebihan yang dimiliki peserta didik.

Pemberian umpan balik sangat penting untuk meningkatkan motivasi peserta didik dan juga menghasilkan prestasi belajar yang lebih baik lagi. Dengan umpan balik peserta didik akan mengetahui sejauh mana perkembangan belajar yang telah dihasilkan (Nikolas, 1989 : 42).

Gagne dalam model pemrosesan informasi mengemukakan delapan fase dalam suatu tindakan belajar yaitu , (1) motivasi ; (2) pemahaman ; (3) pemerolehan ; (4) penyimpanan ; (5) pemanggilan / ingatan kembali ; (6) generalisasi ; (7) penampilan/perlakuan dan (8) umpan balik. Pentingnya peranan umpan balik juga dikemukakan oleh Wiggins dalam Khalsa (2008 : 58) yang mengingatkan pengajar jangan melewatkan memberikan umpan balik kepada peserta didik. Pemberian umpan balik berupa pujian atau koreksi sangat penting oleh karena membantu peserta didik melanjutkan dan mengerjakan hal yang ingin dikerjakan (mampu memotivasi peserta didik). Adanya umpan balik menawarkan kepada peserta didik berupa informasi untuk pengubahan positif serta mendukung pemahaman peserta didik sehingga dapat berfikir mendalam mengenai pembelajaran dengan rasa percaya diri yang tinggi.

Menurut Nikolas (1989 : 38) umpan balik sebagai informasi tentang pengaruh keluaran dari sistem yang disodorkan kembali ke dalam sistem. Dalam proses belajar, umpan balik didasarkan atas pengamatan mengenai penampilan peserta didik, yaitu mengenal apakah proses belajarnya sudah mencapai tujuan atau belum. Sedangkan Magill (1993 : 82) mengatakan bahwa umpan balik sering dipakai dalam proses belajar untuk meningkatkan kemampuan belajar peserta didik. Umpan balik adalah suatu faktor yang sangat penting dalam mengontrol prilaku untuk mencapai hasil belajar yang diinginkan.
Cepat lambatnya atau berhasil tidaknya peserta didik menguasai suatu jenis keterampilan sangat ditentukan oleh tepat tidaknya umpan balik yang diberikan oleh guru, pelatih maupun teman peserta didik dalam berlatih. Pentingnya umpan balik, yaitu : (1) sebagai sumber informasi. (2) sebagai penguatan dan (3) sebagai motivasi. Dengan kata lain, umpan balik adalah semua yang dirasakan oleh pelaku setelah melakukan tugas gerakan itu sendiri, dan melibatkan penglihatan, pendengaran, siasat dan masukan sensori kinestetik (Kleinman, 1983 : 199). Oxendine (1968 : 111) menyatakan bahwa umpan balik dapat dibedakan dalam beberapa bentuk berdasarkan tipe pemberian informasi, waktu penerimaan informasi, sumber informasi, perasaan penerimaan informasi, waktu pemberian informasi, dan faktor-faktor lain.berdasarkan waktu penerimaan informasi menurut Stallings (1982 : 86) mengatakan bahwa balikan informasi dapat diberikan segera sesudah selesainya penampilan atau sesudah ditunda beberapa lama. Pemberian informasi tambahan sesudah selesainya penampilan dapat mengganggu pengelolaan individu dan menghalangi keuntungan yang dapat diserap dari balikan intrinsik yang diberikan oleh keterampilan tersebut. Pemberian knowledge of result secara tidak cepat atau dengan segera sesudah penampilan, tidak akan memberikan pengaruh yang positif terhadap kemahiran dan kurang penting Magill (1995: 235)

Menurut Drowatzky (1985 : 45) menyatakan bahwa balikan (umpan balik) dapat digambarkan sebagai bagian dari keluaran atau respons yang disodorkan kembali kepada pelaku sebagai masukan. Selanjutnya ia mengklasifikasikan balikan pertama yang disebut "balikan hakiki" yaitu umpan balik langsung yang dapat dirasakan dan dilihat, balikan kedua yaitu balikan tambahan/buatan, umpan balik ini diterima setelah ada informasi dari luar yaitu dari guru yang telah mengamati pelaku dalam melakukan gerakan hal ini dapat langsung diinformasikan ataupun melalui alatalat bantu yang lain, dalam hal ini dapat menggunakan alat bantu cek list agar dapat memberikan informasi balikan bagi setiap peserta didik sehingga dapat terekam setiap gerakan yang salah dan benar, dengan demikian informasi balikan secara psikologis dapat menimbulkan rangsangan dan motivasi bagi peserta didik. 
Umpan balik langsung adalah umpan balik yang diberikan setiap selesainya melakukan keseluruhan ataupun rangkaian satu set gerakan dari beberapa tahapan gerakan yang ada, sedangkan umpan balik tertunda adalah umpan balik yang diberikan setelah selesainya satu bahagian gerakan dari beberapa bahagian gerakan yang ditampilkan. Umpan balik tidak sama dengan penilaian. Umpan balik hanya dimaksudkan untuk mencari informasi sampai dimana peserta didik mengerti bahan pelajaran yang telah dibahas. Selain itu peserta didik diberi kesempatan untuk memeriksa diri sampai dimana mereka mengerti bahan pelajaran tersebut, sehingga mereka dapat melengkapi pengertian-pengertian yang belum lengkap dan sejauh mana uraian yang diberikan dapat tersampaikan secara baik dan jelas.

Pada umumnya pengajar kurang memikirkan perlunya mengadakan umpan balik, sehingga ia tidak tahu efek dari pengajaran yang ia berikan. Baru setelah seluruh rangkaian pembelajaran telah selesai diberikan, terlihat pada waktu tes peserta didik belum mengerti secara baik bahan yang diajarkan, dan itu berarti suatu keterlambatan, sebaliknya apabila pengajar menyadari pentingnya umpan balik, maka pengajaran yang diberikan akan menjadi lebih efektif. Ad Rooijakers (1991 : 47) mengatakan pengajar dapat mengetahui hasil pembelajaran sebelumnya dengan cara : (1) Lewat kesan yang diperoleh selama jam pelajaran itu sendiri. (2) lewat informasi sederhana dari pihak peserta didik melalui pertanyaan-pertanyaan lisan yang diajukan oleh pengajar selama atau setelah jam pelajaran. (3) Lewat informasi tertulis dari pihak peserta didik yang diperoleh melalui ujian singkat, dan (5) mempelajari tentamen atau ujian yang diadakan pada akhir pelajaran. Tiga hal yang pertama berhubungan dengan umpan balik yang dilakukan terhadap tiap jam pelajaran, dan hal ini disebut umpan balik pembelajaran. Setiap umpan balik pengajaran menentukan isi pelajaran berikutnya, oleh karena itu jelas bahwa umpan balik tidak hanya perlu bagi pengajar, tetapi juga bagi peserta didik.

Umpan balik langsung adalah informasi yang segera diberikan oleh guru atau teman dalam berlatih ketika peserta didik selesai melakukan keseluruhan ataupun rangkaian satu set gerakan dari beberapa tahapan gerakan yang ada. Dalam pemberian umpan balik langsung, peserta didik diharapkan dapat melakukan perbaikan setelah diberikan informasi langsung oleh guru. Gerakan dari tendangan shooting yang telah dilakukan harus diberikan umpan balik langsung dan jangan ditunda-tunda. Tomlison (1989 : 36) menyatakan Umpan balik langsung tersebut perlu segera diberikan kepada peserta didik agar dapat memperhitungkan prestasi atau hasil belajar selanjutnya. Bila jangka waktu antara pelaksanaan gerakan dengan saat penerimaan umpan balik tersebut cukup lama, dengan sendirinya motivasi untuk memperbaiki diri akan hilang. Selanjutnya Magill (1995 : 67) menyatakan pemberian pemahaman secara cepat atau dengan segera sesudah penampilan akan memberikan pengaruh yang positif terhadap penampilan. Ciri-ciri umpan balik langsung adalah : (1) perolehan balikan intrinsik lebih banyak diserap. (2) Secara penerimaan informasi kognitifnya lebih dapat menerima dikarenakan tidak tergesa-gesa kemungkinan balikan informasi lebih banyak dapat diserap. (3) Jumlah pengulangan (repetisi) lebih banyak. (4) Umpan balik diberikan setelah rangkaian gerakan atau tahapan gerakan selesai dilaksanakan. Umpan balik tertunda adalah informasi yang diberikan guru, atau teman dalam belajar atau berlatih ketika peserta didik selesai melakukan rangkaian-rangkaian gerakan dalam beberapa unit percobaan. Dalam pemberian umpan balik tertunda ada waktu yang harus diperhatikan. Menurut Stalling (1982 : 54) umpan balik tidak langsung dapat diberikan sesudah penampilan pertama dari gerakan selesai dilakukan. Sedangkan Schidt (1998 : 75) menyatakan bahwa selama penundaan peserta didik agaknya memproses informasi pengetahuan tentang hasil dan memutuskan tentang apa yang akan dikerjakan pada percobaan tersebut. dalam hal ini umpan balik tidak langsung bagi seorang peserta didik, yaitu setiap peserta didik yang telah menyelesaikan bagian gerakan yang benar. Dengan demikian pemberian umpan balik tertunda pada shooting adalah setiap peserta didik diberikan umpan balik setelah selesai melakukan bagian -bagian gerakan. Ciri-ciri umpan balik tidak langsung : (1) Perolehan balikan intrinsik lebih sedikit yang dapat diserap. (2) Secara penerimaan informasi kognitifnya kurang dapat menerima dikarenakan informasi yang diberikan terlampau lama. (3) Balikan informasi kemungkinan lebih sedikit diserap. (4) Umpan balik diberikan setiap kali selesai melakukan 
rangkaian atau tahapan gerakan selesai dilaksanakan.

Motorik dan gerak merupakan kedua istilah yang sering dianggap sama, karena kedua istilah tersebut sangat sulit dibatasi secara konkrit, bahkan Harrow (1977 : 38) menggunakan istilah tersebut dengan motor and movement. Hal yang sama juga dinyatakan oleh Kiraim (1992 : 56) motorik adalah suatu peristiwa laten yang meliputi keseluruhan proses pengendalian dan pengaturan fungsi organ tubuh baik secara fisiologis maupun psikis sehingga terjadinya gerakan. Selanjutnya ia menambahkan bahwa gerak adalah perubahan tempat, posisi dan kecepatan tubuh atau bagian tubuh manusia yang terjadi dalam suatu dimensi ruang dan waktu dan dapat diamati secara obyektif. Menurut Singer (1967 : 43) kemampuan motorik diduga sebagai kemampuan seseorang untuk menguasai berbagai kegiatan motorik (termasuk olahraga).

Kemampuan motorik dapat juga dipahami sebagai indikator dari tingkat kemahiran atau penguasaan suatu hal yang memerlukan gerak tubuh. Penguasaan suatu kemampuan motorik merupakan sebuah proses dimana seseorang mengembangkan seperangkat respons ke dalam suatu pola gerak yang terkoordinasi, terorganisir dan terpadu. Setiap kemampuan motorik membutuhkan pengorganisasian gerakan otot, baik dalam aspek tempat dan waktu. Pengorganisasian otot menurut tempat berarti bahwa terdapat sekelompok otot yang terpilih untuk melakukan suatu gerakan, pengorganisasian menurut waktu berarti bahwa otot-otot berkontraksi atau relaksasi harus terjadi pada waktu yang tepat dan serasi.

Dalam belajar motorik, pengertian gerak tidak hanya dilihat dari perubahan tempat, posisi dan kecepatan tubuh melakukan aksi motorik dalam olahraga tetapi gerak juga diartikan sebagai hasil atau penampilan yang nyata dari proses motorik. Kemampuan motorik merupakan sasaran program pendidikan jasmani, dengan memiliki kemampuan motorik yang tinggi akan memudahkan seseorang untuk menguasai dirinya secara efesien dalam berbagai situasi gerak. Menurut Oxendine (1968 : 267) kemampuan motorik adalah gambaran dari salah satu kecakapan dalam melakukan bermacam-macam keterampilan dasar dan aktivitas fisik secara keseluruhan. Kemudian menurut Singer (1967 : 45) kemampuan motorik diidentifikasikan sebagai penampilan kemampuan olahraga yang dimiliki oleh seseorang secara individu yang berguna sebagai landasan untuk melakukan bermacammacam gerakan keterampilan motorik. Sedangkan Lutan (1990 : 65) menyatakan bahwa kemampuan motorik lebih tepat disebut sebagai kapasitas dari seseorang yang berkaitan dengan pelaksanaan dan peragaan suatu keterampilan yang relatif melekat setelah masa kanak-kanak. Begitu pula yang dinyatakan oleh Well dan Murray (1985 : 79) bahwa kemampuan motorik adalah kapasitas penampilan seseorang dalam melakukan berbagai tugas gerak. Selanjutnya Lutan (1992 : 18) menyatakan bahwa kemampuan (ability) merupakan suatu kapasitas umum yang berkaitan dengan prestasi berbagai macam keterampilan atau lebih tepatnya dikatakan sebagai a general capacity of the individual that relates to the performance of a variety of skills or task. Sebagai contoh kemampuan yang dikategorikan sebagai ability adalah unsur kecepatan gerak (speed of movement)

Gambaran konsep kemampuan motorik dari Oxendine di atas pada dasarnya meliputi konsep penguasaan kemampuan dasar dan aktivitas kemampuan fisik. Di dalam menjelaskan konsepnya. Oxendine menggunakan pendapat dari Clarke's, dimana unsur-unsur kemampuan motorik terdiri dari kekuatan otot, daya tahan otot, daya tahan cardiovascular, kecepatan, kelincahan, keseimbangan, power otot, koordinasi matalengan dan mata-kaki. Menurut Singer (1967 : 23) motorik merupakan bagian dari kualitas gerak kontrol tubuh yang meliputi gerakan melempar, menangkap, memukul, menendang, berkelok-kelok, lari, berjalan, melompat, dan meluncur. Kemudian gambaran kemampuan motorik dari Lutan (1990 : 68) menjelaskan pengaruh faktor biologis dianggap sebagai kekuatan utama terhadap kemampuan motorik dasar seseorang. Dimana kemampuan motorik dasar itulah yang kemudian berperan sebagai landasan bagi perkembangan keterampilan, sedangkan keterampilan banyak tergantung pada pkemampuan dasar. Kemampuan dasar inilah yang nantinya akan berperan melaksanakan keterampilan olahraga.

Dasar kemampuan motorik yang terkoordinasi baik otot yang lebih kecil memainkan peran yang besar. Defenisi kemampuan menurut Sajoto (1988 : 31) kemampuan dapat diuraikan dengan kata seperti otomatik, cepat, dan akurat. Meskipun 
demikian, salah apabila menganggap kemampuan sebagai tindakan tunggal yang sempurna. Setiap pelaksanaan sesuatu yang terlatih, walaupun hanya menulis huruf $\mathrm{A}$, merupakan satu rangkaian koordinasi beratusratus otot yang rumit dan melibatkan perbedaan isyarat dan koreksi kesalahan yang berkesinambungan.

Kemampuan yang dipelajari dengan baik akan berkembang menjadi kebiasaan. Hilgard (1982 : 24) menyatakan bahwa kebiasaan sebagai setiap bentuk yang berulang dengan cepat dan lancar, tersusun dari pola gerakan yang dapat dikenal. Umumnya seseorang kurang memperhatikan rincian kegiatan kebiasaanya, kebiasaan relatif otomatis serta pola gerakannya berulang. Kemampuan motorik tidak akan berkembang melalui kematangan saja, melainkan kemampuan itu harus dipelajari. Jika hal tersebut diabaikan, maka kemampuan motorik anak akan berada di bawah kemampuannya. Sebagai contoh, apabila pada waktu peserta didik mempelajari kemampuan menendang dalam shooting sedikit bimbingan yang diberikan, maka kemampuan tersebut dipelajarinya lebih lambat dan kurang efisien daripada peserta didik yang ditunjukan bagaimana cara menendang yang baik dan sempurna, kemampuan yang diperolehnyapun juga akan berbeda.

Cara yang digunakan peserta didik untuk mempelajari suatu kemampuan motorik sangat penting untuk memperoleh kualitas kemampuan yang dipelajari. Meskipun setiap cara pada saatnya nanti mungkin peserta didik mampu mengembangkan suatu kemampuan, sebagian cara jauh lebih efisien dan kualitas hasilnya jauh lebih baik ketimbang dengan cara yang lain. Tidak ada hal-hal yang sifatnya umum perihal kemampuan motorik, melainkan setiap jenis kemampuan motorik setiap individu mempunyai perbedaan tertentu, sehingga setiap kemampuan motorik peserta didik harus diketahui oleh guru.

Dalam tahap awal mempelajari kemampuan motorik, gerakan tubuh masih janggal dan tidak terkoordinasi serta banyak melakukan gerakan yang tidak perlu. Sebagai contoh, pada waktu belajar menendang, peserta didik menendang dengan ujung kakinya,akan tetapi dengan praktek lebih banyak, kemampuan motorik anak tersebut akan membaik dan gerakannya menjadi terkoordinasi.
Pada saat berkembangnya kemampuan motorik, meningkat pula tingkat kecepatan, akurasi, kekuatan dan efisiensi gerakan. Kemampuan motorik yang paling cenderung memperlihatkan perbaikan yang terbesar adalah kemampuan yang dipelajari di sekolah atau dalam kelompok bermain yang dibimbing. Kemampuan tersebut termasuk menulis, menggambar, melukis, memahat, menari, dan berkaitan dengan gerakan dalam olahraga. Alasan adanya peningkatan kemampuan tersebut adalah karena guru atau pembimbing harus mengarahkan usaha peserta didik kesaluran yang benar. Selain itu, mereka juga berjaga-jaga terhadap kemungkinan timbulnya kesalahan dan bersedia memperbaiki kesalahan itu sebelum praktek ulang menjadi kebiasaan. Akibatnya, anak memperlihatkan kecakapan yang lebih besar dalam kemampuan yang diterimanya melalui bimbingan ketimbang dalam kemampuan yang dipelajarinya melalui teman sebaya atau dalam kemampuan yang dipelajarinya di rumah karena orang tuanya kurang memiliki waktu untuk membimbingnya.

Hipotesis di dalam penelitian ini sebagai berikut: 1.Hasil belajar shooting pada pembelajaran sepak bola siswa yang diberikan umpan balik langsung lebih tinggi dibandingkan dengan pemberian umpan balik tidak langsung.2. Hasil belajar shooting pada pembelajaran sepak bola siswa yang memiliki tingkat kemampuan motorik tinggi lebih tinggi dibandingkan dengan siswa yang memiliki tingkat kemampuan motorik rendah.3.Terdapat interaksi antara pemberian umpan balik dan kemampuan motorik terhadap hasil belajar shooting pada pembelajaran siswa di Sekolah Menengah Pertama Negeri di kecamatan Langsa kota Kota Langsa.

\section{METODE}

Populasi dalam penelitian ini adalah seluruh Siswa SMPN 7, yang terdiri dari kelas VII-I yang berjumlah 25 orang, kelas VII-2 yang berjumlah 24 orang, kelas VII-3 yang berjumlah 25 orang dan kelas VII-4 berjumlah 26, sehingga jumlah siswa putra SMPN 7 Langsa adalah 100 orang, Untuk siswa SMPN 1 terdiri dari kelas VII-1 yang berjumlah 27 orang, kelas VII-2 yang berjumlah 24 orang, kelas VII-3 berjumlah 25, dan kelas VII-4 berjumlah 25 orang, sehingga jumlah siswa putra SMPN 1 adalah 101 orang. Dengan demikian jumlah keseluruhan populasi adalah 201 orang. Berdasarkan keadaan populasi 
tersebut akan diambil dua kelompok belajar yang menjadi sampel penelitian, hal ini sesuai dengan desain penelitian yang dipilih. Pemilihan sampel dilakukan dengan teknik cluster random sampling dengan pengacakan kelas dari masing-masing sekolah sehingga sampel penelitian adalah kelas VII-1 yang berjumlah 25 orang dan kelas VII-3 yang berjumlah 25 orang, dan kelas VII-4 berjumlah 26 orang sehingga sampel untuk sekolah SMPN 7 adalah 76 orang, kelas VII-1 berjumlah 27 orang dan VII-3 berjumlah 25 orang, dan VII-4 berjumlah 25 orang sehingga sampel untuk sekolah SMPN 1 sebanyak 77 orang. Jumlah sampel seluruhnya adalah 153 orang.

Anggota sampel dibagi menjadi dua kelompok untuk mendapatkan dua perlakuan yang berbeda yaitu kelompok belajar kelas VII-1 dan VII-3 dan VII-4 SMPN 7 diberikan umpan balik langsung, kelas VII-1 dan VII-3 dan VII-4 SMPN 1 diberikan umpan balik tertunda. Sebelum perlakuan diberikan, seluruh siswa dari kedua kelas sampel terlebih dahulu diberikan tes kemampuan motorik untuk mengukur tingkat kemampuan motorik siswa. Dari hasil perolehan skor masingmasing siswa dibuat peringkat berdasarkan hasil skor kemampuan motorik. Selanjutnya masing-masing kedua kelas sampel ini ditetapkan kelompok siswa yang memiliki kemampuan motorik tinggi yaitu : 1 kelas berjumlah 6 orang dan 2 kelas berjumlah 7 orang dan kemampuan motorik rendah terdiri dari 1 kelas berjumlah 6 orang dan 2 kelas berjumlah 7 orang.

Metode yang digunakan dalam penelitian ini adalah metode quasi eksperimen. Dengan alasan metode ini dipakai untuk membandingkan mana yang lebih baik antara umpan balik langsung dan umpan balik tertunda. Kemudian metode ini dipakai karena semua variabel bebas (variabel eksperimen), yang menjadi ruang lingkup penelitian adalah : (1) umpan balik langsung (2) umpan balik tertunda. Kemudian satu variabel terikat yaitu hasil belajar shooting pada sepakbola, sedangkan variabel moderator adalah kemampuan motorik, yang terdiri dari : (1) kemampuan motorik tinggi (2) kemampuan motorik rendah, selain itu dalam penelitian ini menggunakan kelas yang tersedia tanpa mengubah kondisi kelas tersebut.

Penentuan desain merujuk pada pendapat Sudjana, yaitu unit-unit eksperimen dikelompokan dalam sel sedemikian rupa sehingga unit-unit eksperimen di dalam sel relatif homogen dan banyak unit eksperimen di dalam sel sama dengan banyak perlakuan yang diteliti. Perlakuan dilakukan secara acak kepada unit-unit eksperimen di dalam setiap sel. Adapun matrik rancangan faktorial $2 \times 2$ Teknik analisis data dalam penelitian ini menggunakan analisis deskriptif dan analisis inferensial. Teknik analisis deskriptif dimaksudkan untuk mendeskripsikan data penelitian melipuiti mean, median, standard deviasi dan kecenderungan data. Data yang telah diperoleh selanjutnya disajikan dalam bentuk tabel distribusi frekuensi dan histogram. Teknik analisis inferensial digunakan untuk menguji hipotesis penelitian dengan menggunakan teknik analisis varians (ANAVA) dua jalur. Dalam menggunakan ANAVA dua jalur perlu dipenuhi beberapa syarat yaitu: 1) data yang digunakan harus berdistribusi normal, maka dilakukan uji normalitas dengan menggunakan uji Lilifors, 2) Data harus memiliki varians populasi homogen, maka harus dilakukan uji homogenitas varians dengan menggunakan Fisher dan uji Bartlet. Penggunaan teknik ini dengan maksud agar hasil tes akhir yang dicapai oleh subyek penelitian benar-benar karena pengaruh dari perlakuan yang diberikan selama penelitian. Taraf signifikan yang digunakan dalam penelitian ini adalah $\alpha=0,05$,

Apabila Uji Anava 2 jalur signifikan, dan ada interaksi antara pemberian umpan balik dengan kemampuan motorik maka diadakan uji lanjut. Selanjutnya Jika besar sampel dari masing-masing sel dalam rancangan penelitian sama, maka analisis dilanjutkan dengan Uji Tuckey, dan jika selanjutnya besar sampel dari masing-masing sel dalam rancangan penelitian berbeda, maka analisis dilanjutkan dengan Uji Scheffe.

\section{HASIL DAN PEMBAHASAN}

Berdasarkan dari hasil penelitian diperoleh 80 data berupa hasil belajar Shooting siswa dari keseluruhan sampel yang berjumlah 153 siswa. Data tersebut diperoleh dari sampel penelitian yang tersebar dalam dua kelas perlakuan dengan perincian 40 data diperoleh dari kelas yang diberi pembelajaran dengan umpan balik langsung dan 40 data diperoleh dari kelas yang diberi pembelajaran dengan umpan balik tertunda. Masing-masing kelas perlakuan dibagi lagi kedalam dua kelompok, yaitu yang memiliki kemampuan motorik 
tingggi dan kelompok yang memiliki kemampuan motorik rendah. Adapun deskripsi data hasil belajar shooting dari masing-masing kelompok dapat dilihat pada Tabel 1 berikut:

Tabel 1. Rangkuman Data Penelitian Hasil Belajar Shooting

\begin{tabular}{|l|c|c|c|c|c|c|c|c|}
\hline $\begin{array}{c}\text { Hasil } \\
\text { Observasi }\end{array}$ & N & ST & SR & RS & $\begin{array}{c}\text { Rata- } \\
\text { rata }\end{array}$ & SD & Me & Mo \\
\hline UBL & 40 & 76 & 56 & 20 & 68,00 & 5,00 & 67,93 & 67,50 \\
\hline UBT & 40 & 73 & 56 & 18 & 66,45 & 4,55 & 66,41 & 66,75 \\
\hline MT & 40 & 76 & 56 & 20 & 67,95 & 5,24 & 67,88 & 69,90 \\
\hline MR & 40 & 73 & 56 & 17 & 66,50 & 4,16 & 66,41 & 66,75 \\
\hline UBLMT & 20 & 76 & 69 & 7 & 72,10 & 2,20 & 73,61 & 73,96 \\
\hline UBLMR & 20 & 69 & 56 & 13 & 63,90 & 3,32 & 64,07 & 63,90 \\
\hline UBTMT & 20 & 69 & 56 & 13 & 63,80 & 3,90 & 64,50 & 62,70 \\
\hline UBTMR & 20 & 73 & 62 & 11 & 69,10 & 3,19 & 69,17 & 69,60 \\
\hline
\end{tabular}

Sebelum dilakukan analisis varians (ANAVA), terlebih dahulu dilakukan uji persyaratan analisis yaitu uji normalitas dan uji homogenitas. Uji normalitas skor hasil shooting dilakukan dengan uji Liliefors dengan taraf signifikan $\alpha=0,05$. Ringkasan hasil uji normalitas dapat dilihat pada Tabel 2 berikut:

Tabel 2. Rangkuman Hasil Uji Normalitas Data

\begin{tabular}{|c|c|c|c|c|}
\hline Kelompok & $\mathbf{n}$ & Lo & $\mathbf{L t}$ & Kesimpulan \\
\hline 1 & 40 & 0,091 & 0,140 & Normal \\
\hline 2 & 40 & 0,113 & 0,140 & Normal \\
\hline 3 & 40 & 0,091 & 0,140 & Normal \\
\hline 4 & 40 & 0,091 & 0,140 & Normal \\
\hline 5 & 20 & 0,159 & 0,190 & Normal \\
\hline 6 & 20 & 0,136 & 0,190 & Normal \\
\hline 7 & 20 & 0,164 & 0,190 & Normal \\
\hline 8 & 20 & 0,188 & 0,190 & Normal \\
\hline
\end{tabular}

Uji homogenitas varians untuk masing-masing kelompok dari setiap perlakuan menggunakan uji Fisher dan uji Barlet dengan signifikansi $\alpha=0,05$.

Rangkuman perhitungan uji homogenitas kelompok sampel siswa yang diberikan umpan balik langsung dan umpan balik tertunda dapat dilihat pada Tabel 3 berikut:

Tabel 3. Perhitungan Homogenitas Data Hasil Penelitian

\begin{tabular}{|c|c|c|c|c|}
\hline No & Sampel & dk & $\log \mathbf{S i}^{2}$ & $(\mathrm{dk}) \log \mathrm{Si}^{2}$ \\
\hline 1 & $\begin{array}{l}\text { Umpan balik langsung pada siswa yang } \\
\text { memiliki kemampuan motorik tinggi }\end{array}$ & 19 & 0,68 & 13,00 \\
\hline 2 & $\begin{array}{l}\text { Umpan balik langsung pada siswa yang } \\
\text { rendah memiliki kemampuan motorik rendah }\end{array}$ & 19 & 1,04 & 19,82 \\
\hline 3 & $\begin{array}{l}\text { umpan balik tertunda pada siswa yang } \\
\text { memiliki kemampuan motorik tinggi }\end{array}$ & 19 & 1,18 & 22,47 \\
\hline 4 & $\begin{array}{l}\text { umpan balik tertunda pada siswa yang } \\
\text { memiliki kemampuan motorik rendah }\end{array}$ & 19 & 1,01 & 19,16 \\
\hline
\end{tabular}

Uji homogenitas interaksi antara interaksi Umpan Balik dan Kemampuan Motorik digunakan rumus barlet. Berdasarkan perhitungan formula barlet diperoleh $\chi^{2}{ }_{\text {hitung }}=6,00$ sedangkan harga $\chi_{0,95(3)}^{2}=7,815$ dengan demikian dapat dilihat bahwa $\chi^{2}{ }_{\text {hitung }}<\chi^{2}{ }_{\text {tabel }}$ sehingga dapat diambil kesimpulan bahwa data-data skor hasil shooting siswa berasal dari varians yang homogen 
Setelah dilakukan pengujian kedua persyaratan analisis yakni uji normlaitas dan uji homogenitas, maka dapat dipastikan bahwa persyaratan yang harus dipenuhi oleh data penelitian dalam rangka penggunaan teknik analisis varian (ANAVA) telah dipenuhi, maka teknik analisis tersebut telah dapat digunakan. Pengujian hipotesis satu dan hipotesis dua dilakukan dengan analisis varian (ANAVA). Untuk keperluan pengujian hipotesis tersebut data yang diperlukan dapat dilihat pada tabel 20, dan perhitungan ANAVA secara lengkap dapat dilihat pada lampiran. Hasil perhitungan yang diperoleh dari hasil perhitungan dengan ANAVA dirangkum dalam tabel perhitungan analisis varian seperti pada tabel 4 .

Tabel 4. Ringkasan Hasil Perhitungan ANAVA Skor Hasil Belajar Shooting pada Taraf $\alpha=0,05$

\begin{tabular}{|c|c|c|c|c|c|c|}
\hline $\begin{array}{c}\text { Sumber } \\
\text { varians }\end{array}$ & JK & Dk & RJK & Fhitung & Ftabel & keterangan \\
\hline Antar Kolom & 48,05 & 1 & 48,05 & 4,654 & 3,967 & Signifikan \\
Antar Baris & 42,5 & 1 & 42,05 & 4,073 & 3,967 & Signifikan \\
Interaksi & 911,25 & 1 & 911,25 & 88,268 & 3,967 & Signifikan \\
\hline $\begin{array}{c}\text { Dalam } \\
\text { kelompok }\end{array}$ & 784,6 & 76 & 10,324 & & & \\
\hline Total & 1785,95 & 79 & & & & \\
\hline
\end{tabular}

Untuk menguji apakah hasil Shooting yang diberikan umpan balik langsung lebih tinggi daripada hasil Shooting yang diberikan umpan balik tertunda, maka digunakan teknik analisis varians (ANAVA). Pengujian dilakukan terhadap hipotesis statistik:

$\mathrm{H}_{0}: \mu_{A 1} \leq \mu_{A 2}$

$\mathrm{H}_{a}: \mu_{A 1}>\mu_{A 2}$

Atau hipotesis yang menyatakan bahwa:

$\mathrm{H}_{0}$ : Hasil Belajar Shooting pada siswa yang diberikan Umpan Balik Langsung lebih kecil atau sama dengan Hasil Shooting Siswa yang diberikan Umpan Balik Tertunda

$\mathrm{H}_{a}$ : Hasil Belajar Shooting pada siswa yang diberikan umpan balik langsung lebih besar/tinggi daripada hasil shooting siswa yang diberikan umpan balik tertunda

Dari hasil perhitungan dengan ANAVA seperti pada tabel 20 diperoleh bahwa $\mathrm{F}_{\text {hitung }}=$ 4,654 dan $\mathrm{F}_{\text {tabel }}=3,967$ pada taraf signifikansi $\alpha$ $=0,05$. Hal ini berarti $F_{\text {hitung }}>F_{\text {tabel, }}$, dengan demikian menunjukkan bahwa hipotesis nol $\left(\mathrm{H}_{0}\right)$ ditolak dan hipotesisi alternatif (Ha) diterima. Dengan demikian bahwa hipotesis penelitian yang menyatakan bahwa hasil belajar shooting pada siswa yang diberikan umpan balik langsung lebih tinggi daripada hasil shooting siswa yang diberikan umpan balik tertunda teruji kebenarannya.

Berdasarkan data yang diperoleh juga menunjukkan bahwa rata-rata hasil Shooting siswa yang diberikan umpan balik langsung $(68,00)$ lebih tinggi daripada hasil Shooting siswa yang diberikan umpan balik tertunda
$(66,45)$. Berdasarkan hasil perbandingan ratarata dan pengujian ANAVA yang diperoleh dapat disimpulkan hasil Shooting pada siswa yang diberikan umpan balik langsung lebih tinggi daripada siswa yang diberikan umpan balik tertunda.

Untuk menguji apakah hasil Shooting yang memiliki kemampuan motorik tinggi lebih tinggi daripada hasil Shooting yang memiliki kemampuan motorik rendah, maka digunakan teknik analisis varians (ANAVA). Pengujian dilakukan terhadap hipotesis statistik:

$\mathrm{H}_{0}: \mu_{B 1} \leq \mu_{B 2}$

$\mathrm{H}_{a}: \mu_{B 1}>\mu_{B 2}$

Atau hipotesis yang menyatakan bahwa:

$\mathrm{H}_{0}$ : Hasil Belajar Shooting pada siswa yang memiliki kemampuan motorik tinggi lebih kecil atau sama dengan Hasil Shooting Siswa yang memiliki kemampuan motorik rendah

$\mathrm{H}_{a}$ : Hasil Belajar Shooting pada siswa yang memiliki kemampuan motorik tinggi lebih besar/tinggi daripada Hasil Shooting Siswa yang memiliki kemampuan motorik rendah

Dari hasil perhitungan dengan ANAVA seperti pada tabel 20 diperoleh bahwa $F_{\text {hitung }}=$ 4,073 dan $\mathrm{F}_{\text {tabel }}=3,967$ pada taraf signifikansi $\alpha$ $=0,05$. Hal ini berarti $F_{\text {hitung }}>F_{\text {tabel, }}$ dengan demikian menunjukkan bahwa hipotesis nol $\left(\mathrm{H}_{0}\right)$ ditolak dan hipotesisi alternatif (Ha) diterima. Dengan demikian bahwa hipotesis penelitian yang menyatakan bahwa hasil belajar shooting pada siswa yang memiliki kemampuan motorik tinggi lebih baik daripada hasil 
shooting siswa yang memiliki kemampuan motorik rendah teruji kebenarannya.

Berdasarkan data yang diperoleh juga menunjukkan bahwa hasil rata-rata hasil Shooting siswa yang memiliki kemampuan motorik tinggi $(67,95)$ lebih tinggi daripada hasil Shooting siswa yang memiliki kemampuan motorik rendah $(66,5)$. Berdasarkan hasil perbandingan rata-rata dan pengujian ANAVA yang diperoleh dapat disimpulkan hasil Shooting pada siswa yang memiliki kemampuan motorik tinggi lebih tinggi daripada siswa yang memiliki kemampuan motorik rendah.

Untuk menguji apakah ada atau tidaknya interaksi antara pemberikan umpan balik dan kemampuan motorik terhadap hasil Shooting siswa maka digunakan teknik analisis varians (ANAVA). Pengujian dilakukan terhadap hipotesis statistik:

$\mathrm{H}_{0}: \mathrm{A} \times \mathrm{B}=0$

$\mathrm{H}_{a}: \mathrm{A} \times \mathrm{B} \neq 0$

Atau hipotesis yang menyatakan bahwa:
$\mathrm{H}_{0}$ : tidak terdapat interaksi antara pemberian umpan balik dan kemampuan motorik dengan Hasil shooting Siswa

$\mathrm{H}_{a}$ : terdapat interaksi antara pemberian umpan balik dan kemampuan motorik dengan Hasil shooting Siswa

Dari hasil perhitungan dengan ANAVA seperti pada tabel 20 diperoleh bahwa $\mathrm{F}_{\text {hitung }}=$ 88,268 dan $\mathrm{F}_{\text {tabel }}=3,967$ pada taraf signifikansi $\alpha=0,05$. Hal ini berarti $F_{\text {hitung }}>F_{\text {tabel }}$, menunjukkan bahwa hipotesis nol $\left(\mathrm{H}_{0}\right)$ ditolak dan hipotesis alternatif (Ha) diterima. Dengan demikian bahwa hipotesis penelitian yang menyatakan bahwa terdapat interaksi antara pemberian umpan balik dan kemampuan motorik dengan hasil belajar shooting siswa teruji kebenarannya.

Berdasarkan hasil pengujian hipotesis di atas dapat juga dilihat bahwa terdapat interaksi antara pemberian umpan balik dan kemampuan motorik terhadap hasil Shooting. Interkasi antara pemberian umpan balik dan kemampuan motorik dapat dilihat pada Gambar 1 berikut:

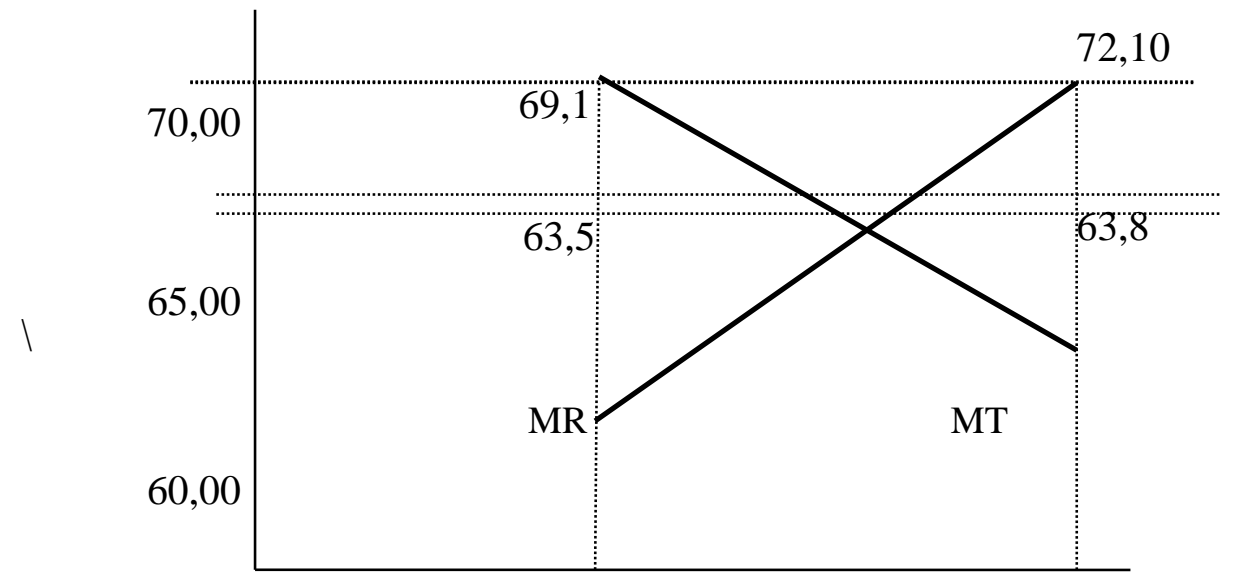

\section{Keterangan:}

UBL : Umpan balik langsung

UBT : Umpan balik tertunda

MT : Motorik tinggi

MR : Motorik rendah

Oleh karena adanya interaksi antara pemberian umpan balik dan kemampuan motorik dalam mempengaruhi hasil shooting siswa serta data yang diperoleh dalam penelitian ini berasal dari sampel yang jumlahnya sama dalam sel ANAVA, maka perlu di adakan uji lanjut dengan menggunakan Uji Tuckey. Adapun ringkasan hasil Uji Tuckey terdapat pada Tabel 5.

Tabel 5. Ringkasan Hasil Uji Tuckey

\begin{tabular}{|c|c|c|}
\hline $\begin{array}{c}\text { Nilai Kelompok yang } \\
\text { Dibandingkan }\end{array}$ & \multirow{2}{*}{$\mathbf{Q}_{\text {hitung }}$} & $\mathbf{Q}_{\text {tabel }}$ \\
\cline { 3 - 3 } & 11,421 & $\boldsymbol{\alpha}=\mathbf{0 , 0 5}$ \\
\hline$\mu_{11}$ dengan $\mu_{12}$ & 11,421 \\
\hline
\end{tabular}




\begin{tabular}{|c|c|c|}
\hline $\begin{array}{c}\text { Nilai Kelompok yang } \\
\text { Dibandingkan }\end{array}$ & \multirow{2}{*}{$\mathbf{Q}_{\text {hitung }}$} & $\mathbf{Q}_{\text {tabel }}$ \\
\cline { 3 - 3 } & & $\boldsymbol{\alpha}=\mathbf{0 , 0 5}$ \\
\hline$\mu_{11}$ dengan $\mu_{21}$ & 11,560 & 3,96 \\
\hline$\mu_{11}$ dengan $\mu_{22}$ & 4,178 & 3,96 \\
\hline$\mu_{21}$ dengan $\mu_{22}$ & 7,382 & 3,96 \\
\hline$\mu_{21}$ dengan $\mu_{12}$ & $0,139(\mathrm{~ns})$ & 3,96 \\
\hline$\mu_{12}$ dengan $\mu_{22}$ & 7,242 & 3,96 \\
\hline
\end{tabular}

\section{PENUTUP}

Berdasarkan hasil penelitian dan pembahasan yang telah diuraikan pada bab sebelumnya, maka diambil kesimpulan sebagai berikut:

1. Hasil belajar Shooting siswa SMP yang diberikan umpan balik langsung lebih tinggi dari siswa yang diberikan umpan balik tertunda

2. Hasil belajar shooting siswa yang memliki kemampuan motorik tinggi lebih tinggi dari siswa yang memiliki kemampuan motorik rendah

3. Terdapat interaksi antara pemberian umpan balik dan kemampuan motorik terhadap hasil belajar shooting siswa SMP. Untuk siswa yang memiliki kemampuan motorik tinggi lebih efektif dalam meningkatkan hasil belajar shooting jika diberikan umpan balik langsung, sedangkan untuk siswa yang memiliki kemampuan motorik rendah ternyata pemberian umpan balik tertunda lebih efektif dalam meingkatkan hasil belajar shooting

\section{DAFTAR PUSTAKA}

Ahmadi. 2007. Perkembangan Anak. Bandung : Ganesha.

Barsch. 1998. Teaching and Learning. New York

Campbell Linda. 1996. Teaching and Learning. Massachusset : Allyn and Bacon.
Fauzi Daral. 2009. Tes Keterampilan Sepak Bola Usia 10-12 Tahun. Jakarta :

Departemen Pendidikan Nasional.

Drowatzky. 1975. Motor Learning Principles and practice. Burgess Publishing Company.

Gagne, R.M 1977. The Conditions of Learning. New York

Gultom. 1994. Metode dalam Pembelajaran. Jakarta : Departemen Pendidikan dan Kebudayaan.

Hadiati Lita. 2011.Pengaruh Pemberian Umpan Balik dan Dimensi Kepribadian

Terhadap Hasil Belajar KAU Mahasiswa Psikologi Universitas Sumatera Utara. Medan : Unimed

Harrow 1977. Dasar-Dasar Sepakbola. Bandung : Pakar Jaya.

Harsuki. 2003. Perkembangan Olahraga Terkini. Jakarta : Rajagrafindo Persada.

Hilgard. 1982. Training and Assasment. New York.

Kiraim, P.Y. 1992. Belajar Motorik. Jakarta : Bumi Aksara.

Karwono. 2008. Berbagai Metode Pembelajaran. Jakarta : Bumi Aksara

Khalisa. 1989. Metode Umpan Balik untuk Pembelajaran Efektif. Yogyakarta : Diva Press.

Lutan, R. 1988. Belajar Keterampilan Motorik. Jakarta : Depdikbud, Dirjen Dikti. 